\title{
AMELIORATIVE EFFECT OF GINGER (ZINGIBER OFFICINALE ROSCOE) ON THYROID GLAND ACTIVITY IN RATS
}

\author{
DALIA MOUSTAFA ${ }^{1}$, EID ABDELHAMEED ${ }^{2}$ and HASSAN AHMED ${ }^{3}$ \\ ${ }^{1}$ Physiology Department, Faculty of Veterinary Medicine, Aswan University, Aswan, 81528 Egypt \\ ${ }^{2}$ Physiology Department, Faculty of Veterinary Medicine, Beni-Suef University, Beni-Suef, 62511 Egypt \\ ${ }^{3}$ Physiology Department, Faculty of Veterinary Medicine, South Valley University, Qena, 83523 Egypt
}

Received: 20 June 2017; $\quad$ Accepted: 10 July 2017

\begin{abstract}
The aim of this study is to investigate the relationship between Ginger administration and thyroid gland function. Ginger was orally administered daily to male albino rats at a dose level of either 50 or $100 \mathrm{mg} / \mathrm{kg}$ for one month. Blood samples and thyroid glands were collected after 15 and 30 days and also 10 days after stopping Ginger administration for hormonal analysis and histopathological examination. It was found that T3 elevated significantly 15 days after administration regardless of the dose. Moreover, this elevation became non-significant after 30 days. Interestingly, this change in T3 is reversible and returned to normal level after stopping Ginger administration. Regarding to T4, both doses of Ginger elevated T4 after 15 and 30 days. Likewise, T4 decreased and returned to normal level after stopping Ginger administration. Both dose level, 50 and $100 \mathrm{mg} / \mathrm{kg}$ of Ginger elevated TSH after 15 and 30 days, but this elevation after $100 \mathrm{mg} / \mathrm{kg}$ was less potent. During the recovery period, almost no change in TSH level was observed. The effect of Ginger for a long period has a deleterious effect on thyroid follicles which appear dilated and empty from colloidal materials.
\end{abstract}

Key words: Ginger, Thyroid, Thyroxin, Tri-iodothyronine, TSH

\section{INTRODUCTION}

Ginger (Zingiber officinale Roscoe) is a plant that has green-purple flowers and an aromatic underground stem called a rhizome (Sertie et al., 1991). It is commonly used for cooking and medicinal purposes. Historically, Ginger has been used in Asian medicine for treatment of stomachaches, nausea, and diarrhea. Today, Ginger is used as a therapy for nausea caused by motion or that after surgical operation, chemotherapy, pregnancy, rheumatoid arthritis, osteoarthritis and muscle pain. The use of Ginger, specifically its medicinally active rhizome has gained popularity among most physicians in the last decades (Mascolo et al., 1989). The pharmacological effects of fresh and dried rhizome of Ginger including anti-platelet, antioxidant, anti-tumor, anti-rhinoviral, antihepatotoxic and anti-arthritic activities back to ancient China and India (Kamatchouing et al., 2002). In addition, Ginger extracts have been reported to have a potent androgenic activity in male rats (Amin

Corresponding author: Dr. HASSAN AHMED E-mail address: Hassan-younes@vet.svu.edu.eg Present address: Physiology Department, Faculty of Veterinary Medicine, South Valley University. Qena, 83523 Egypt. and Hamza, 2006). These androgenic activities have a useful effect on treating spermatogenesis disorder and poor sperm function (khaki et al., 2009). At the same time, recent studies reported the role of Ginger in body metabolism such as improvement of lipid derangement, fructose overconsumption and liver lipogenesis (Gao et al., 2012). On the other side, it has been found a new function of Ginger as antiinflammatory in gastrointestinal tract as its protective effect against colitis by regulation of cytokine-related pathway (Hsiang et al., 2013). The current study tries to find out the effect of Ginger on thyroid gland function by oral administration at dose level of 50 and $100 \mathrm{mg} / \mathrm{kg}$ body weight by monitoring of thyroid hormones and histopathological examination of thyroid gland.

\section{MATERIALS AND METHOD}
Animals:
Ninety adult male albino rats, Sprague Dawley strain, with an average weight of $(160 \pm 20 \mathrm{~g})$ were obtained from the private laboratory animal farm, Tanta city, Egypt. Animals were transferred to Physiology Department, Faculty of Veterinary Medicine, South Valley University, Qena. Rats were housed in clean plastic cages and maintained on a $12 \mathrm{~h}$ light/dark 
cycle and at temperature of $26 \pm 2{ }^{\circ} \mathrm{C}$ with ad libitum access to food and water for two weeks to be acclimatized laboratory environment.

\section{Ginger:}

Ginger was bought from MEPACO-MEDIFOOD, which is an Arab company that supplies pharmaceuticals and medicinal plants (Enshas, Sharkeya, Egypt) in the form of 30 tablets each contained $400 \mathrm{mg}$ of Ginger. Ginger was dissolved in NaCL $0.9 \%$, then orally administered every day via stomach tube at two different doses 50 and 100 $\mathrm{mg} / \mathrm{kg}$ body weight (Khaki et al., 2009).

\section{Experimental design:}

Ninety animals were randomly distributed into three groups 30 rats in each. The first one, is a control received saline orally, whereas the second and third groups received Ginger orally at doses 50 and 100 $\mathrm{mg} / \mathrm{kg}$ body weight, respectively via stomach tube daily for 30 days (Khaki et al., 2012). Fifteen and thirty days after Ginger oral administration, 10 animals from each group were anesthetized by diethyl ether then blood samples were collected from retro-orbital Venus plexus. Blood samples were centrifuged at $3000 \mathrm{RPM}$ for $15 \mathrm{~min}$ then sera were separated and kept in $-20^{\circ} \mathrm{C}$ until hormonal analysis (T3, T4 and TSH). Rats were sacrificed and thyroid gland was collected for histopathological study. The remaining animals in each group were kept without any treatment for 10 days for recovery. After the end of the recovery period, blood samples were collected and animals were sacrificed with extraction of the thyroid gland for histopathological examination.

\section{Histological and histopathological examination:}

Thyroid glands were rapidly washed in saline solution to remove the blood. Thyroid specimens were removed rapidly from saline and fixed in $10 \%$ neutral buffered formalin, then processed up in paraffin blocks. Sections of $5 \mu \mathrm{m}$ thick were prepared and stained with hematoxylin and eosin for histopathological studies (Drury and Wallington, 1980).

\section{Hormonal assay:}

Enzyme-linked immunosorbent assay (ELISA) used for analysis of T3, T4 and TSH using microstrip reader (Stat Fax®4700, USA) at wave length $450 \mathrm{~nm}$. Following kits were used, T3 AccuLite VAST CLIA
Kits (Monobind Inc, Lake forest, USA) (Gharib et al., 1971). Aviva Total Thyroxine EIA kits (Aviva Systems Biology, San Diego, USA) (Walker, 1977) and TSH AccuLite VAST CLIA Kits (Monobind Inc, Lake forest, USA) (Hopton and Harrap, 1986).

\section{Statistical analysis:}

Results were analyzed statistically by SPSS and Excel 2010 software. All data were expressed as mean \pm standard error (SE) and differences between groups were analyzed by using student's $t$-Test. Values of $\mathrm{P}<0.05$ were considered significant.

\section{RESULTS}

\section{I - Tri-iodothyronine}

Data in Table (I) and Fig. (1) revealed that, administration of Ginger for 15 and 30 days at a dose level of 50 and $100 \mathrm{mg} / \mathrm{kg}$ induced different effects on serum T3 level. Serum level of T3 significantly increased $(\mathrm{P}<0.001) 15$ days after injection of both doses $(0.48 \pm 0.03$ and $.060 \pm 0.05$, respectively $)$ compared with the corresponding control rats $(0.24 \pm$ 0.02). Moreover, the prolonged time of Ginger administration to 30 days revealed non-significant increase of serum T3 after $50 \mathrm{mg} / \mathrm{kg}(0.26 \pm 0.02)$ while, higher dose $(100 \mathrm{mg} / \mathrm{kg})$ elevated $\mathrm{T} 3$ significantly $(\mathrm{P}<0.01)(0.40 \pm 0.04)$ compared with corresponding control $(0.25 \pm 0.02)$.

Table (I) showed a comparison between T3 level in the same column, after the same dose in different period of administration. Serum T3 level decreased 30 days after injection of $50 \mathrm{mg} / \mathrm{kg}$ significantly $(\mathrm{P}<0.001)(0.26 \pm 0.02)$ compared with $\mathrm{T} 3$ level after 15 days $(0.48 \pm 0.03)$. Likewise; it is found that after $100 \mathrm{mg} / \mathrm{kg}$ Ginger administration, T3 level significantly decreased $(\mathrm{P}<0.01)$ after 30 days $(0.40$ $\pm 0.04)$ compared with 15 days $(0.60 \pm 0.05)$. After the end of Ginger administration period, surprisingly, level of T3 during recovery period in 50 and 100 $\mathrm{mg} / \mathrm{kg}$-treated groups was $(0.20 \pm 0.01$ and $0.21 \pm$ 0.01 , respectively) returned to level of control rats $(0.26 \pm 0.03)$. In addition, comparing T3 level with in the same column of recovery period revealed that serumT3 decreased significantly after injection of 50 $(\mathrm{P}<0.01)$ and $100 \mathrm{mg} / \mathrm{kg}(\mathrm{P}<0.001)(0.20 \pm 0.03$ and $0.21 \pm 0.01$, respectively) compared with their levels after 30 days of administration. 
Table I: Serum T3 level (ng/ml) of control, 50 and $100 \mathrm{mg} / \mathrm{kg} \mathrm{BW-treated} \mathrm{groups} \mathrm{as} \mathrm{well} \mathrm{as} \mathrm{recovery} \mathrm{period.}$

Time after treatment

After 15 days
Control

$0.24 \pm 0.02$
$50 \mathrm{mg} / \mathrm{kg} \mathrm{B.W}$
II A

$0.60 \pm 0.05$

\begin{tabular}{|c|c|c|c|}
\hline After 30 days & $0.25 \pm 0.02$ & $\underset{0.26 \pm 0.02}{\mathrm{I}}$ & $\begin{array}{c}\text { II } \quad \text { BI } \\
0.40 \pm 0.04\end{array}$ \\
\hline $\begin{array}{c}\text { Recovery } \\
\text { (10 days from stop treatment) }\end{array}$ & $0.26 \pm 0.03$ & $\begin{array}{c}\text { II } \\
0.20 \quad \pm 0.01\end{array}$ & $\begin{array}{c}\mathrm{I} \\
0.21 \pm 0.01\end{array}$ \\
\hline
\end{tabular}

A: Values significantly differ from the corresponding control at $(P<0.001)$ in the same row.

$B$ : Values significantly differ from the corresponding control at $(P<0.01)$ in the same row.

I: Values differ significantly from each other at $(P<0.001)$ in the same column.

II: Values differ significantly from each other at $(P<0.01)$ in the same column

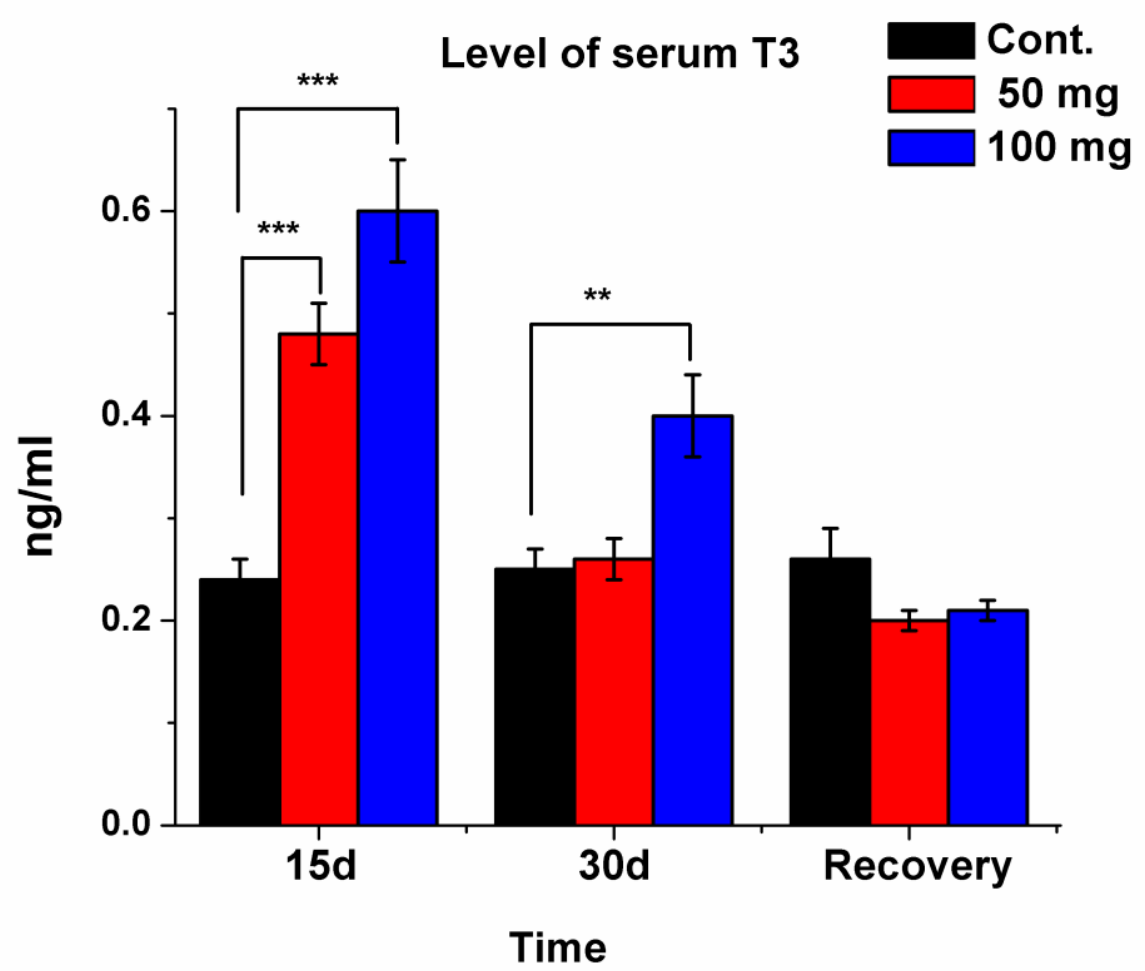

Figure (1): Serum T3 level in control rats as well as those received ginger in dose 50 and $100 \mathrm{mg} / \mathrm{kg}$ after 15 and 30 days as well as after stop Ginger treatment (Recovery). It is clear that, T3 increased after Ginger administration then return to basal level in recovery period. $(* * * \mathrm{P}<0.001)$ and $(* * \mathrm{P}<0.01)$. 


\section{II - Thyroxine}

Unlike T3, serum T4 level is less affected by 50 and $100 \mathrm{mg} / \mathrm{kg}$ Ginger administration. There is nonsignificant increase after administration of both doses $(3.60 \pm 0.70$ and $4.50 \pm 0.90$, respectively) compared with corresponding control $(2.83 \pm 0.50)$ after 15 days of administration. The same results were obtained 30 days after administration $(3.08 \pm 0.60$ and $2.08 \pm 0.04$, respectively) compared with control $(2.87 \pm 0.50)$ (Fig. 2). Depending on the effect of same dose on T4 level in different administration period, there is non-significant decrease in T4 level after 15 and 30 days administration $(3.60 \pm 0.70$ and $3.08 \pm 0.60$, respectively) in $50 \mathrm{mg} / \mathrm{kg}$-treated group. However, there is a significantly decrease $(\mathrm{P}<0.05)$ of serum T4 level $100 \mathrm{mg} / \mathrm{kg}$-treated group after 30 days of administration (2.09 \pm 0.04$)$ compared with 15 days administration $(4.50 \pm 0.90)$ (Table II). Regarding to serumT4 level during recovery period, there was non-significant decrease in serum T4 level in treated groups $(2.10 \pm 0.40$ and $2.13 \pm 0.50)$ compared with their corresponding control rats $(3.40$ $\pm 0.70)$.

Table II: Serum T4 level $(\mu \mathrm{g} / \mathrm{dl})$ in control, 50 and $100 \mathrm{mg} / \mathrm{kg}$ B.W-treated groups and recovery period.

\begin{tabular}{|c|c|c|c|}
\hline Time after treatment & Control & $50 \mathrm{mg} / \mathrm{kg} \mathrm{B} . \mathrm{W}$ & $100 \mathrm{mg} / \mathrm{kg} \mathrm{B} . \mathrm{W}$ \\
\hline After 15 days & $2.83 \pm 0.5$ & $3.6 \pm 0.7$ & $\begin{array}{c}\mathrm{I} \\
4.5 \pm 0.9\end{array}$ \\
\hline After 30 days & $2.87 \pm 0.5$ & $3.08 \pm 0.6$ & $\begin{array}{c}\mathrm{I} \\
2.08 \pm 0.04\end{array}$ \\
\hline $\begin{array}{c}\text { Recovery } \\
\text { (10 days from stop treatment) }\end{array}$ & $3.4 \pm 0.7$ & $2.1 \pm 0.4$ & $2.13 \pm 0.5$ \\
\hline
\end{tabular}

I: Values differ significantly from each other at $(P<0.05)$ in the same column.

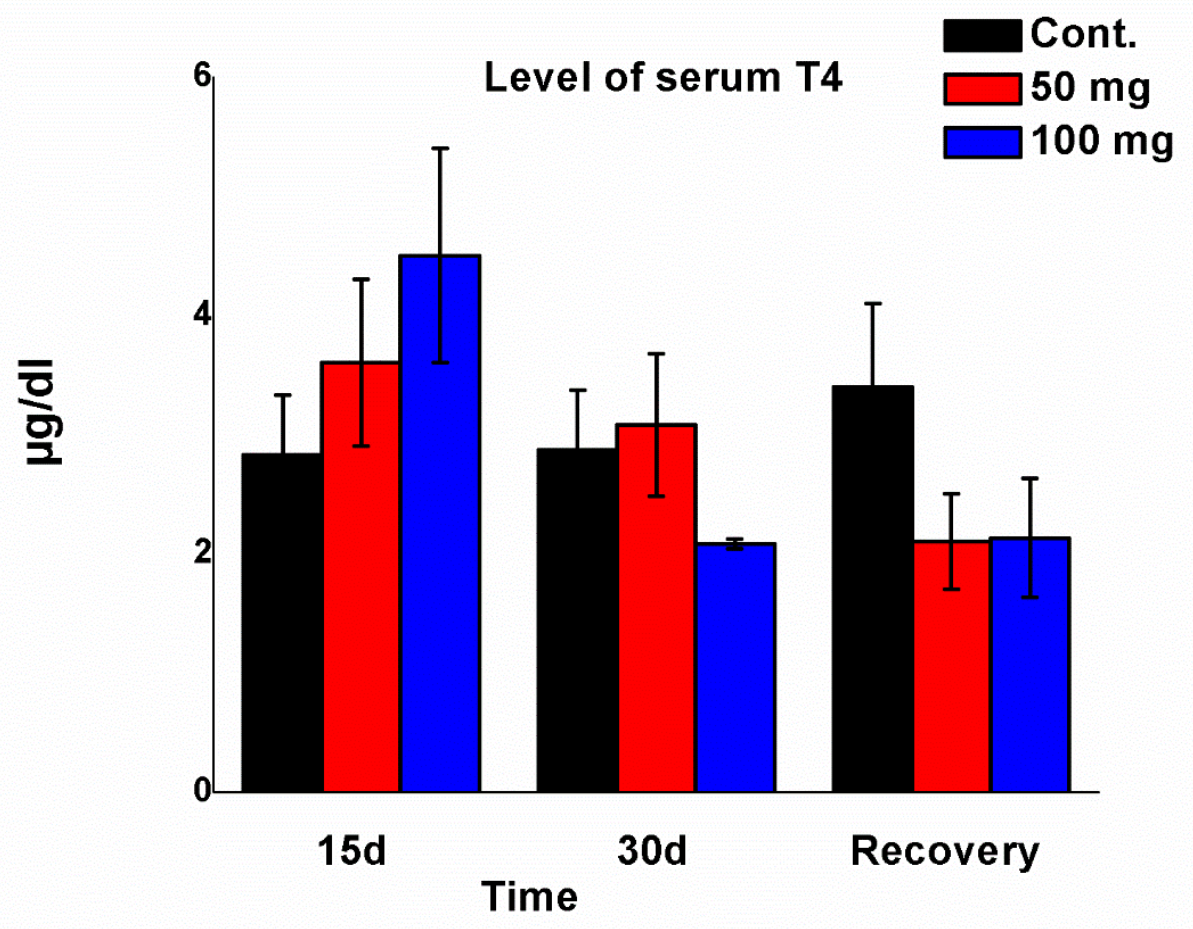

Figure (2): Serum level of T4 after 15 and 30 days of Ginger administration and in recovery period in control rats and those received Ginger 50 and $100 \mathrm{mg} / \mathrm{kg}$. It shows elevation of T4 after 15days and decreased after 30 days (with high dose) from Ginger administration then return to normal level. 


\section{III - Thyroid stimulating hormone}

Ginger administration in 50 and $100 \mathrm{mg} / \mathrm{kg}$ for 15 and 30 days had variable effect on TSH level. Administration of $50 \mathrm{mg} / \mathrm{kg}$ showed non-significant increase of TSH level after 15 (8.20 \pm 1.00) compared with control $(7.10 \pm 0.09)$ and 30 days $(9.36 \pm 1.20)$ compared with corresponding control $(6.53 \pm 0.80)$, respectively. Moreover, the same results were obtained when the rats administered 100 $\mathrm{mg} / \mathrm{kg}$ for $15(7.40 \pm 0.03)$ and 30 days $(7.93 \pm 0.90)$ (Fig. 3) \& (Table III) compared with control group. During the recovery period, there was a nonsignificant increase in serum TSH level in treated groups $(50$ and $100 \mathrm{mg} / \mathrm{kg})(9.40 \pm 1.40$ and 7.27 $\pm 1.10)$ compared with control rats $(6.83 \pm 0.90)$.

Table III: Serum level of TSH $(\mu \mathrm{IU} / \mathrm{ml})$ in control male rats, 50 and $100 \mathrm{mg} / \mathrm{kg} \mathrm{B.W}$-treated groups and recovery period.

\begin{tabular}{cccc}
\hline Time after treatment & Control & $50 \mathrm{mg} / \mathrm{kg} \mathrm{B.} \mathrm{W}$ & $100 \mathrm{mg} / \mathrm{kg} \mathrm{B.} \mathrm{W}$ \\
\hline After 15 days & $7.1 \pm 0.09$ & $8.2 \pm 1.00$ & $7.4 \pm 0.03$ \\
\hline After 30 days & $6.53 \pm 0.8$ & $9.36 \pm 1.2$ & $7.93 \pm 0.9$ \\
\hline $\begin{array}{c}\text { Recovery } \\
\text { (10 days from stop treatment) }\end{array}$ & $6.83 \pm 0.9$ & $9.4 \pm 1.4$ & $7.27 \pm 1.1$ \\
\hline
\end{tabular}

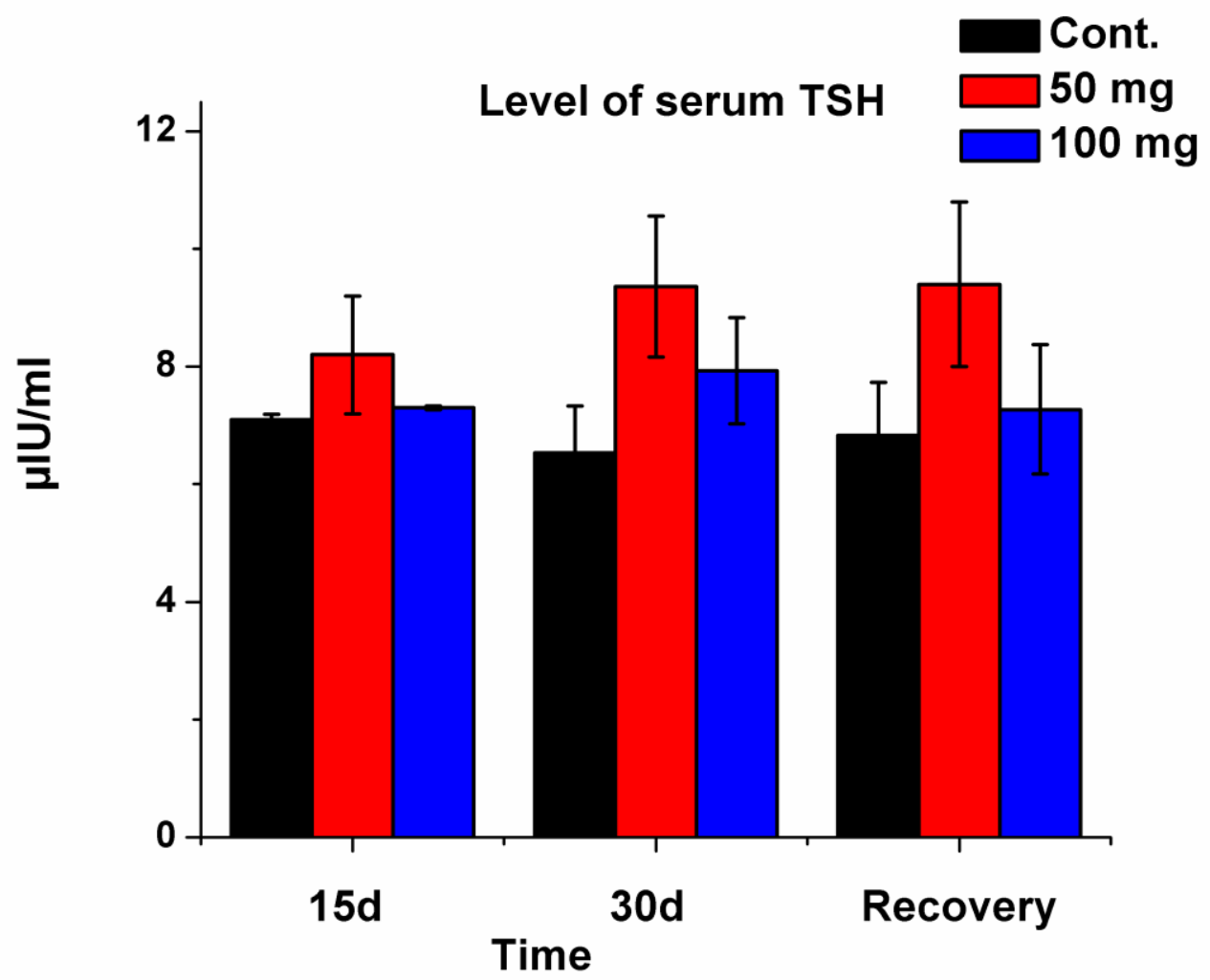

Figure (3): Serum level of TSH after Ginger administration in different periods (15 and 30 days) as well as recovery time. There is small elevation of TSH after Ginger administration especially after prolonged administration. 


\section{IV-Histological and histopathological examination} Thyroid gland of control animals (Fig. 4A) composed of thyroid follicles of varying sizes lined by cuboidal cells containing colloidal materials in different amounts. Normal histological structure of thyroid gland was disturbed after Ginger administration depending on the dose and period of administration. After 15 days of $50 \mathrm{mg} / \mathrm{kg}$ Ginger administration, some thyroid follicles are dilated (Fig. 4B) with colloidal materials. However, other follicles appeared empty and smaller with pale colloidal materials. Thyroid gland is highly affected by higher Ginger dose $(100 \mathrm{mg} / \mathrm{kg})$. After 15 days of administration, some thyroid glands appeared with normal colloid structure (Fig. 4C) while, others were empty and contain desquamated cells in their lumen without colloidal materials in addition to inter-follicular hemorrhage.
On the other side, Ginger administration for 30 days revealed normal histological structure of thyroid gland (Fig. 5A). While, in $50 \mathrm{mg} / \mathrm{kg}$-treated group there was less changes represented by smaller follicle with pale colloidal materials compared with the control (Fig. 5B). Interestingly, thyroid gland of 100 $\mathrm{mg} / \mathrm{kg}$-treated rats showed drastic effect (Fig. 5C); these changes represented by empty follicles and detached epithelial cells. During the recovery period, thyroid follicles showed some histopathological improvement in treated groups. Thyroid follicles recovered after $50 \mathrm{mg} / \mathrm{kg}$ administration to normal structure however, others still empty without colloidal materials with detached epithelial cells (Fig. 6A). On the other side, some thyroid follicles after $100 \mathrm{mg} / \mathrm{kg}$ administration appeared as normal ones with cuboidal cells while, some follicles still affected (Fig. 6B).
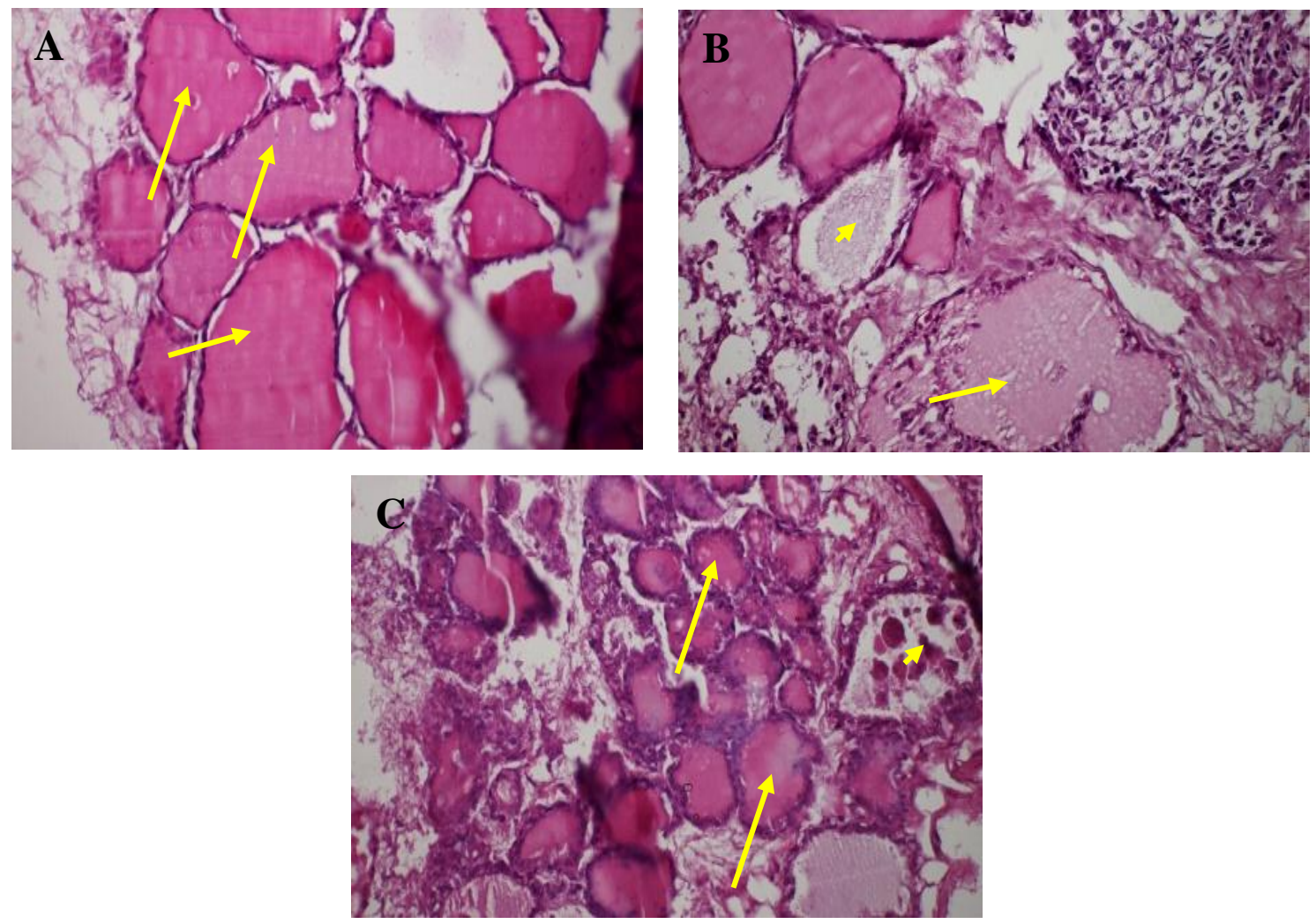

Figure (4): Microscopic photography revealed histological and histopathological structure of thyroid gland in normal (A) and ginger-treated rats (B and C) for 15 days. (A) Normal thyroid follicles (Arrows) in different sizes filled with colloidal materials (X400). (B) Adverse effect of $50 \mathrm{mg} / \mathrm{kg}$ represented by impaired dilated follicles (Arrows) while, others (Arrow head) are smaller, empty or contain pale colloidal materials. (C) Ginger at dose $100 \mathrm{mg} / \mathrm{kg}$ leading to smaller follicles (Arrows) while, others are empty with desquamated cells (Arrow head) (Stain: H\&E, Magnification: X200). 

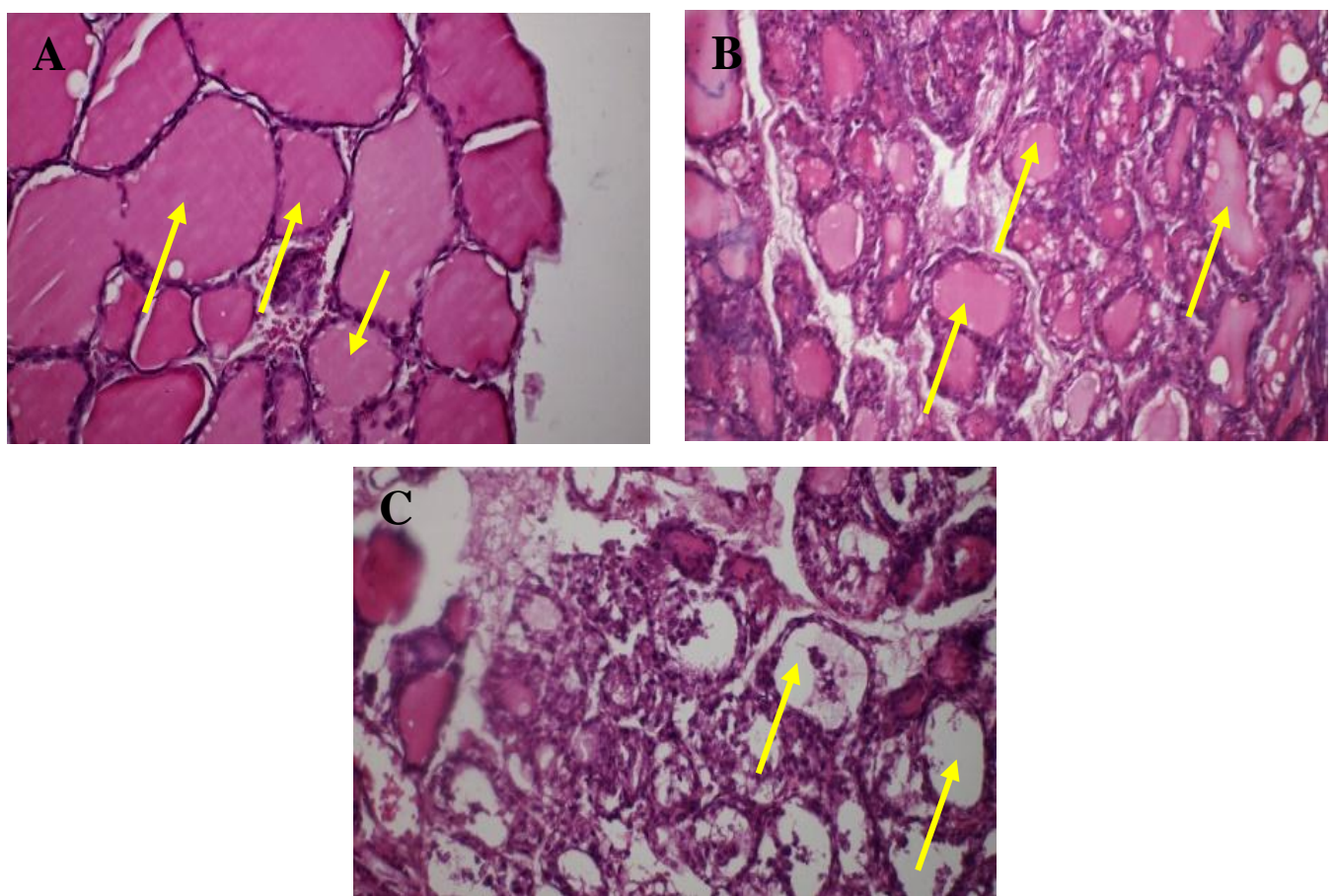

Figure (5): Histological and histopathological findings of thyroid gland in normal (A) and ginger-treated rats (B and $\mathrm{C}$ ) for 30 days. (A) Similar to the previous control rats, there are normal thyroid follicles (Arrows) (X400). (B): At $50 \mathrm{mg} / \mathrm{kg}$ Ginger dose, there is limited effect on thyroid follicles represented by smaller in size (Arrows) (X200). (C) High Ginger dose, $100 \mathrm{mg} / \mathrm{kg}$ has drastic changes in thyroid follicles which appeared empty (Arrows) with detached epithelial cells (Stain: H\&E, Magnification: X400)
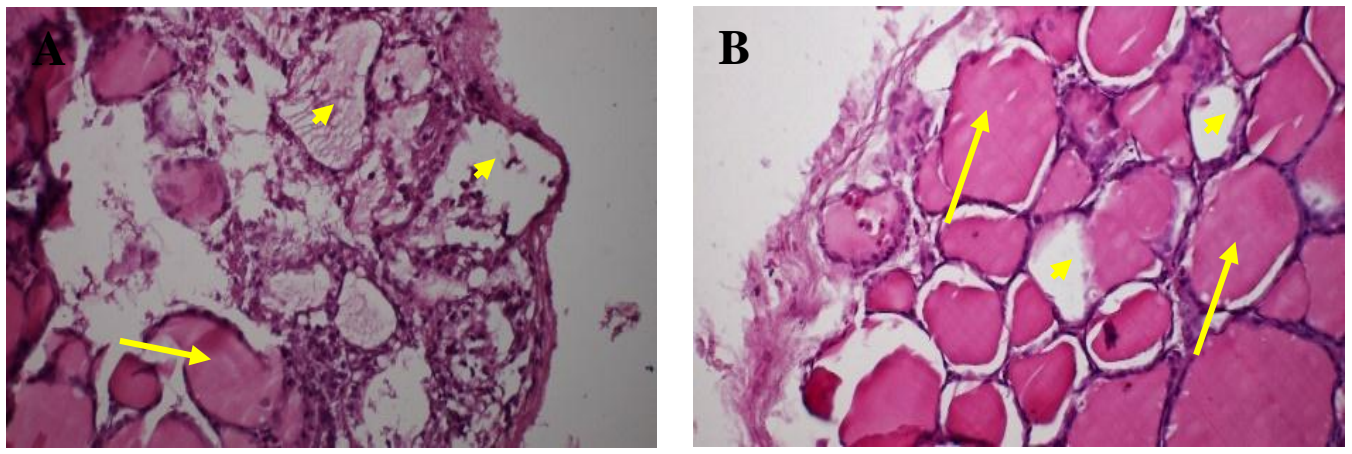

Figure (6): Recovery of some affected thyroid follicles after stop of Ginger administration $50 \mathrm{mg} / \mathrm{kg}$ (A) and $100 \mathrm{mg} / \mathrm{kg}$ (B). (A) Showed some follicles recovered (Arrows) and filled with colloidal materials however, others still empty (Arrow head) (X400). (B) There is a partial recovery of adversely affected follicles, some recovered (Arrow) while, others appeared empty with desquamated cells (Stain: H\&E, Magnification: X400).

\section{DISCUSSION}

The present aimed to find out the effect of the Ginger on thyroid gland after oral administration. The results represent the lost ring in scientific research of Ginger medical uses. All the previous studies shed the light on various medical effect of Ginger such as on cardiovascular function (Ohizumi et al., 1996), antihypertensive effect (Ghayur and Gilani, 2005), on gastrointestinal tract and digestion (Platel and Srinivasan, 1996 and 2000) as it enhances GIT hormones activity. Moreover, these studies extended to include improvement effect of Ginger on testicular function (Khaki et al., 2009 and 2012), anti-oxidant effect (Nassiri et al., 2009 and Khaki et al., 2012), hepatic (Zakhari, 2006) and renal (Sakr et al., 2011) protective and anti-inflammatory effect (Srivastava and Mustafa, 1989 and 1992). The present study clarified that Ginger affected thyroid activity centrally through TSH or locally through thyroid tissue depending on the dose and period of administration. Level of TSH, T3 and T4 elevated after 15 days of Ginger oral administration (50 $\mathrm{mg} / \mathrm{kg}$ ) and this elevation may be due to increase blood supply and nutrients to thyroid follicles. Depending on the previous studies, Ginger increase 
cardiac output subsequently, blood supply to the body in addition, it enhances intracellular metabolism (Shoji et al., 1982). Moreover, histopathological examination revealed dilatation of some thyroid follicles in the same group indicating distention of these follicles with thyroglobulins subsequently with thyroid hormones.

Level of T3 and T4 in continuous elevation after higher dose of Ginger $(100 \mathrm{mg} / \mathrm{kg})$ as well as thyroid follicles filled with thyroglobulins therefore, this elevation during short period administration (15 days) is dose independent. On the other hand, levels of TSH, T3 and T4 during long period administration (30 days) is dose dependent and $50 \mathrm{mg} / \mathrm{kg}$ elevates levels of TSH, T3 and T4. Interestingly, higher dose $(100 \mathrm{mg} / \mathrm{kg})$ within the same period decreases level of TSH and T4 but not T3 that still high. This decrease may be due to inhibitory effect of higher dose of Ginger in prolonged time. As recorded before, high dose of Ginger for long time cause subacute thyroiditis and inhibitory effect on metabolic rate and adenylate energy status (Riewe et al., 2008). Therefore, ending with damage of thyroid follicle membrane and inhibit thyroid hormone synthesis (Sanavi and Afshar, 2010). In addition, histopathological examination confirmed the presence of thyroiditis by detached epithelial lining in some follicles, which appear empty from thyroglobulins.

The most surprising finding is the elevation of $\mathrm{T} 3$ with higher Ginger dose for long time, which may be due to different metabolic effect of Ginger on biosynthesis of T3 and T4 during binding of Diiodotyrosin molecules with each other or with Monoiodotyrosin to from $\mathrm{T} 4$ and $\mathrm{T} 3$, respectively. This change in metabolic effect may enhances T3 and suppress $\mathrm{T} 4$ biosynthesis, but this need to be confirmed by further and advanced study at molecular biological and cellular level. After recovery period, the hormonal changes are reversible and levels of T3 and T4 returned around the normal level in both low and high doses after 15 and 30 days of Ginger administration. At the same time, the histological structure of thyroid follicles revealed that most of affected follicles recovered to normal structure with thyroglobulins in their lumina. Although, some follicles still deteriorated and their lumen still empty with detached epithelial lining, they may be recovered completely if recovery period is longer with normal level of thyroid hormones. Although levels of $\mathrm{T} 3$ and $\mathrm{T} 4$ returned during recovery period to the normal level, TSH still high after low Ginger administration $(50 \mathrm{mg} / \mathrm{kg})$ while, it reduced after high ginger dose $(100 \mathrm{mg} / \mathrm{kg})$. This may be due to feedback mechanism and decreasing level of T3 and T4 from high to basal level.

In conclusion, oral administration of Ginger has stimulatory effect on thyroid hormones after 15 days of administration regardless its dose. On the other hand, prolonged Ginger administration (30 days), T3 elevated with high Ginger dose $(100 \mathrm{mg} / \mathrm{kg})$ however, T4 decreased with the same dose. These changes are TSH independent but they depend on local effect of Ginger on thyroid follicles. This change of hormonal level is reversible due to hormones returned to basal level after stop of Ginger administration.

\section{REFERENCES}

Amin, A. and Hamza, A.A. (2006): Effects of Rosell and Ginger on cisplatin- induced reproductive toxicity in rats. Asian J. Androl., 8(5): 607612.

Drury, R.A. and Wallington, E.A. (1980): Carleton's histopathological technique (pp. 234-239, 4th ed.). Oxford University Press, Oxford, New York, Toronto.

Gao, H.; Guan, T.; Li, C.; Zuo, G.; Yamahara, J.; Wang, J. and Li, Y. (2012): Treatment with Ginger Ameliorates Fructose-Induced Fatty Liver and Hypertriglyceridemia in Rats: Modulation of the Hepatic Carbohydrate Response Element-Binding Protein-Mediated Pathway. Evid Based Complement Alternat Med., 570948.

Gharib, H.; Ryan, R.J.; Mayberry, W.E. and Hockett, T. (1971): Radioimmunoassay for Triiodothyronine (T3): Affinity and Specificity of Antibody for T3. J Clinical Endocrinol., 33, 509-516.

Ghayur, M.N. and Gilani, A.H. (2005): Ginger lowers blood pressure through blockade of voltage dependent calcium channels. J. Cardiovasc. Pharmacol., 45: 74-80.

Hopton, M.R. and Harrap, J.J. (1986): Immunoradiometric assay of thyrotropin as a first line thyroid function test in the routine laboratory. Clinical Chemistry, 32:691-693.

Hsiang, C.Y.; Lo, H.Y.; Huang, H.C.; Li, C.C.; Wu, S.L. and Ho, T.Y. (2013): Ginger extract and zingerone ameliorated trinitrobenzene sulphonic acid-induced colitis in mice via modulation of nuclear factor- $\kappa \mathrm{B}$ activity and interleukin-1 $\beta$ signalling pathway. Food Chem., 136(1):170-177.

Kamtchouing, P.; Mbongue-Fandio, G.Y.; Dimo, T. and Jatsa, H.B. (2002): Evaluation of androgenic activity of Zingiber officinale extract in male rats. Asian J. Androl., 4: 299301

Khaki, A.; Farnam, A.; Badie, A.D. and Nikniaz, H. (2012): Treatment Effects of Onion (Allium cepa) and Ginger (Zingiber officinale) on Sexual Behavior of Rat after Inducing an Antiepileptic Drug (lamotrigine). Balkan Med J., 29: 236-242.

Khaki, A.; Fathiazad, F.; Nouri, M.; Khaki, A.A.; ozanci, C.C.; Ghafari-Novin, M. and Hamadeh, M. (2009): The Effects of Ginger 
on Spermatogenesis and Sperm parameters of Rat. Iranian J. Reprod. MED. 7 (1): 7-12.

Mascolo, N.; Jain, R.; Tain, S.C. and Capasso, F.J. (1989): Ethnopharmacologic investigation of Ginger (Zingiber officinale). J. Ethano Pharmacol., 27 (1-2): 129-140.

Nassiri, M.; Khaki, A.; Ahmadi-Ashtiani, H.R.; Rezazadeh, S.h.; Rastgarm, H. and Gharachurlu, S.h. (2009): Effects of Ginger on Spermatogenesis in Streptozotocin-induced Diabetic Rat. Journal of Medicinal Plants, 8 (31): 118-124.

Ohizumi, Y.; Sasaki, S.; Shibusawa, K.; Ishikawa, K. and Ikemoto, F. (1996): Stimulation of sarcoplastic reticulum $\mathrm{Ca}^{2+}$ ATPase by gingerol analogues. Biol. Pharm. Bull., 19: 1377-1379.

Platel, K. and Srinivasan, K. (1996): Influence of dietary spices or their active principles on digestive enzymes of small intestinal mucosa in rats. International Journal of Food Sciences \& Nutrition, 47: 55-59.

Platel, K. and Srinivasan, K. (2000): Influence of dietary spices and their active principles on pancreatic digestive enzymes in albino rats. Nahrung, 44: 42-46.

Riewe, D.; Grosman, L.; Zauber, H.; Wucke, C.; Fernie, A.R. and Geigenberger, P. (2008): Metabolic and developmental adaptations of growing potato tubers in response to specific manipulations of the adenylate energy status. Plant Physiol., 146:1579-1598.
Sakr, A.S.; Lamfon, A.H. and Essawy, E.A. (2011): Ginger (Zingiber officinale) extract ameliorates metalaxyl fungicide induced nephrotoxicity in albino mice. African Journal of Pharmacy and Pharmacology, 5(2):104-112.

Sanavi, S. and Afshar, R. (2010): Subacute thyroiditis following Ginger (Zingiber officinale) consumption. International Journal of Ayurveda Research, 1(1):47-48.

Sertie, J.A.; Basile, A.C. and Panizza, S. (1991): Pharmacological assay of Cordia verbenacea. III: oral and topical anti-inflammatory activity and gastrotoxicity of a crude leaf extract, J. Ethnopharmacol., 31: 239-247.

Shoji, N.; Iwasa, A.; Jakemoto, T.; Ishida, Y. and Ohizuma, Y. (1982): Cardiotonic principle of Ginger (Zinigiber officinale Roscoe). J. Pharm Sci., 7: 1174-1175.

Srivastava, K.C. and Mustafa, T. (1989): Ginger (Zingiber officinale) and rheumatic disorders. Med Hypotheses, 29 (1):25-28.

Srivastava, K.C. and Mustafa, T. (1992): Ginger (Zingiber officinale) in rheumatism and musculoskeletal disorders. Med Hypotheses, 39 (4):342-348.

Walker, W.H.C. (1977): Introduction: An Approach to Immunoassay. Clin. Chem., 23(2): 384-387.

Zakhari, S. (2006): Overview: how is alcohol metabolized by the body? Alcohol Res Health., 29(4):245-254.

\section{التأثير التحسني للزنجبيل علي نشاط الغدة الارقية في الفئران داليا مصطفي ، عبا عبا الحمبل ، حسن أحمد}

Email: Hassan-younes@vet.svu.edu.eg Assiut University web-site: www.aun.edu.eg

يعتبر الزنجبيل من أهم الأعثاب التي تم اكتشافها قديما وعادة كان يستخدم في الطهي وإكتساب طعم طيب للطعام. انتشر الزنجبيل

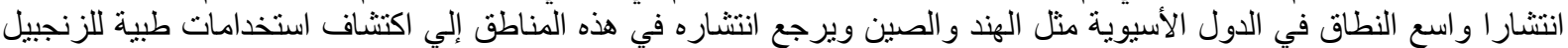

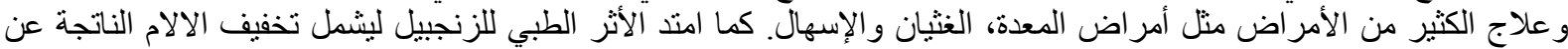

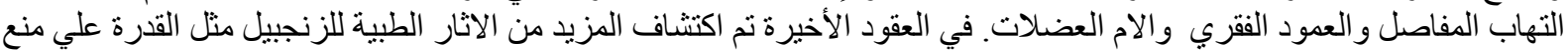

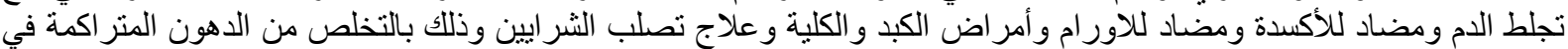

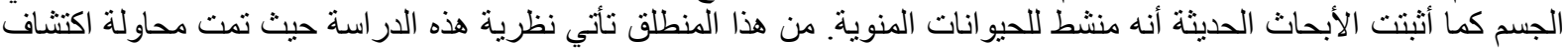

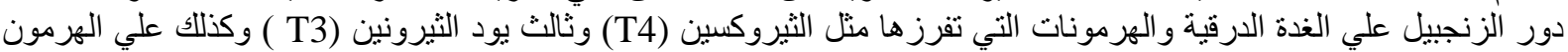

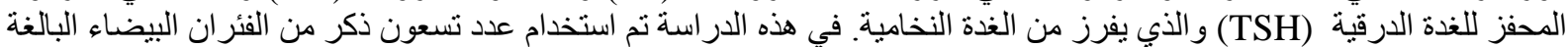

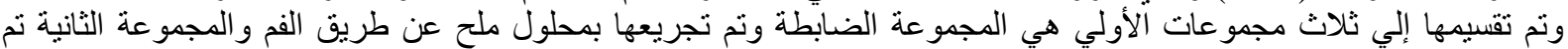

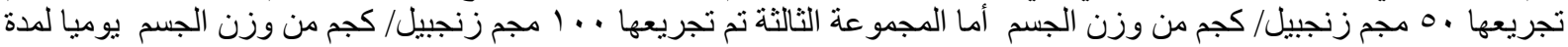

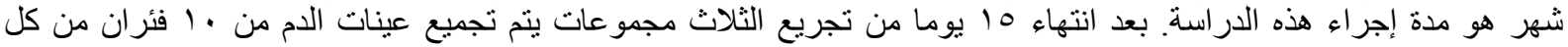

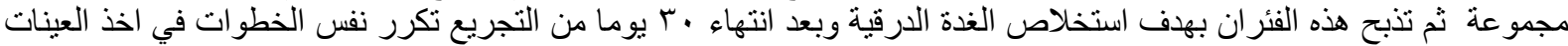

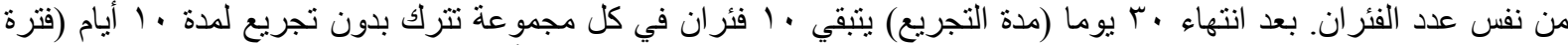

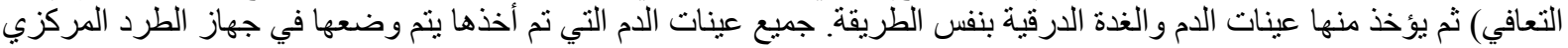

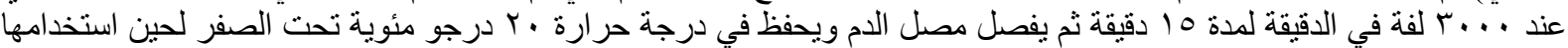

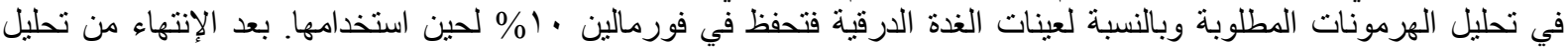

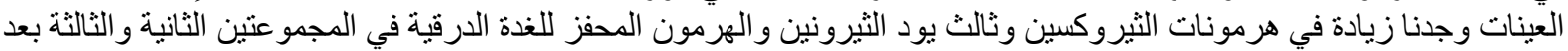

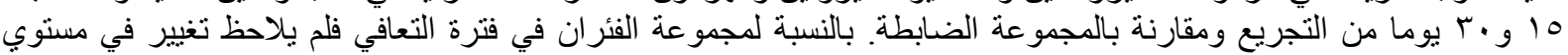

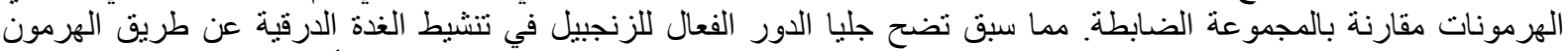

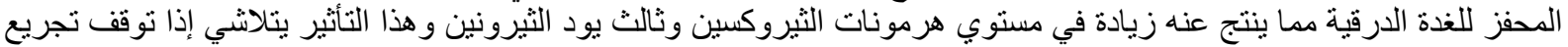

